
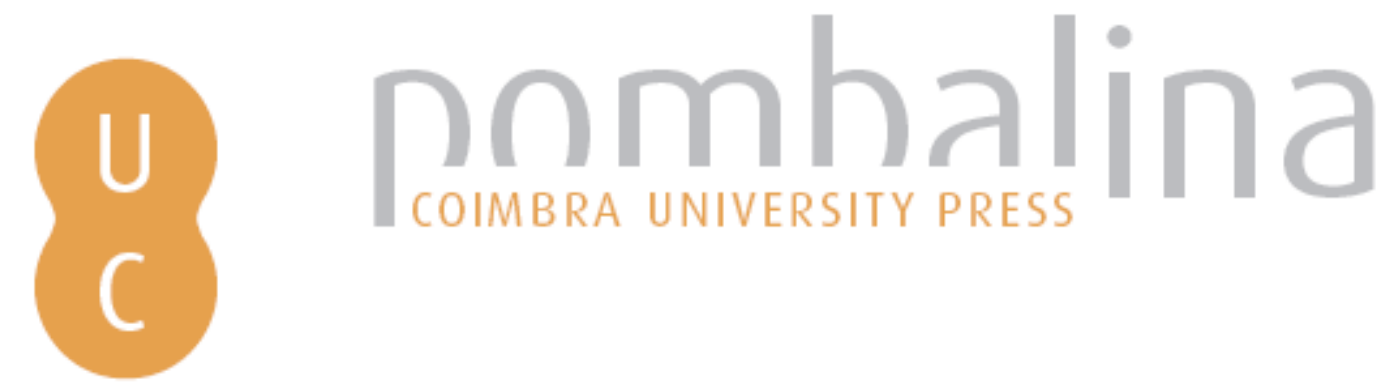

\title{
Assessment of wildfire exposure and vulnerability factors in Alvares, Góis: integration of structural and dynamic factors at the local scale
}

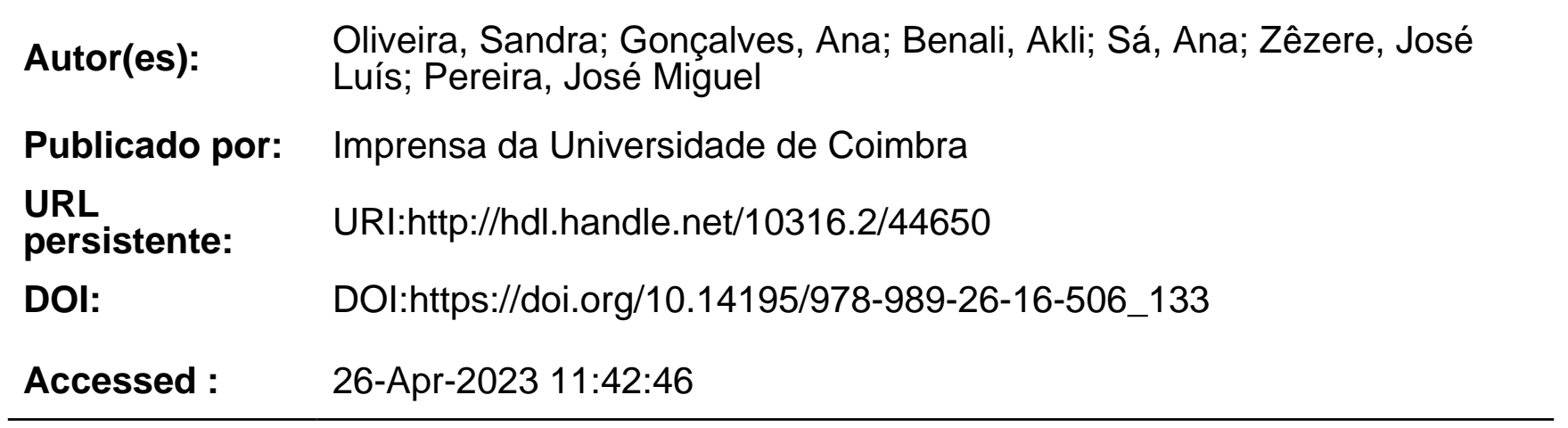

A navegação consulta e descarregamento dos títulos inseridos nas Bibliotecas Digitais UC Digitalis, UC Pombalina e UC Impactum, pressupõem a aceitação plena e sem reservas dos Termos e Condições de Uso destas Bibliotecas Digitais, disponíveis em https://digitalis.uc.pt/pt-pt/termos.

Conforme exposto nos referidos Termos e Condições de Uso, o descarregamento de títulos de acesso restrito requer uma licença válida de autorização devendo o utilizador aceder ao(s) documento(s) a partir de um endereço de IP da instituição detentora da supramencionada licença.

Ao utilizador é apenas permitido o descarregamento para uso pessoal, pelo que o emprego do(s) título(s) descarregado(s) para outro fim, designadamente comercial, carece de autorização do respetivo autor ou editor da obra.

Na medida em que todas as obras da UC Digitalis se encontram protegidas pelo Código do Direito de Autor e Direitos Conexos e demais legislação aplicável, toda a cópia, parcial ou total, deste documento, nos casos em que é legalmente admitida, deverá conter ou fazer-se acompanhar por este aviso.

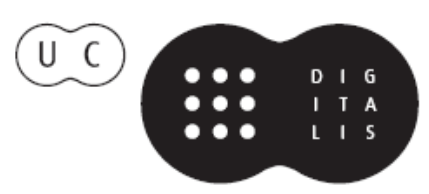




\section{ADVANCES IN}

\section{FOREST FIRE RESEARCH}

\section{8}

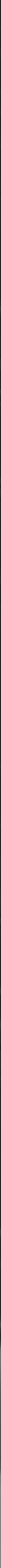


Short contribution - Fire Risk Management

Assessment of wildfire exposure and vulnerability factors in Alvares, Góis: integration of structural and dynamic factors at the local scale

\author{
Sandra Oliveira ${ }^{1 *}$; Ana Gonçalves ${ }^{1}$, Akli Benali ${ }^{2}$, Ana Sá2 ${ }^{2}$ José Luís Zêzere ${ }^{1}$, José Miguel Pereira ${ }^{2}$ \\ ${ }^{1}$ Institute of Geography and Spatial Planning, Universidade de Lisboa, Lisbon, Portugal \\ \{sandra.oliveiral@campus.ul.pt*\} \\ ${ }^{2}$ Forest Research Centre, School of Agriculture, Universidade de Lisboa, Lisbon, Portugal
}

\begin{abstract}
According to climate projections, global warming is associated with increasing temperatures and dry spells in some parts of the world, especially the Mediterranean area. This climate change has already triggered increases in wildfire danger and fire season length in Southern Europe and is expected to amplify in the forthcoming decades. However, it is quite challenging for the scientific community to assess the intensity of these changes, because (i) the trend relies on the greenhouse gases (GHG) emission scenario and (ii) fire occurrence depends on multiple factors (including climate, but not only). A proper assessment of the trend in terms of fire occurrence and of uncertainties associated with this increasing trend, still lacks, especially for the French territory.

Our study refines traditional approaches of fire risk projection under climate change on two aspects: (i) the impact of climate prediction uncertainties on the prediction of fire danger, and (ii) the translation of a danger index into a fire occurrence (per size classes).
\end{abstract}

Keywords: wildfire exposure; vulnerability factors; dynamic approach; local scale; Portugal

\title{
1. Introduction
}

Wildfires are a major threat in Portugal. The year 2017 was particularly severe, with a large burned area extent and heavy impacts on human lives and assets. The civil parish of Alvares (Góis) has been strongly affected by wildfires over the last decades and had $60 \%$ of its surface area burned by a single large wildfire in June 2017. In addition to the land cover dominated by forest fuels and the rugged topography, this area is characterized by a dispersion of small human settlements, inhabited by few elderly people, intermingling with vegetation that occupy what was once farmland and is now abandoned (Moreira et al., 2011; Oliveira, Zêzere, Queirós, \& Pereira, 2017). These particular conditions increase the exposure of this territory to wildfire occurrence and damages.

In this context, and considering the influence of the local features in the implementation of mitigation and adaptation strategies to wildfires, it becomes of high relevance to integrate exposure and vulnerability assessment at the local scale in wildfire management and risk mitigation approaches (Alcasena et al. 2015; Carroll and Paveglio 2016; Paveglio, Prato, et al. 2016).

This research focused on the assessment of exposure and vulnerability of the human settlements (small villages) within a civil parish, with the purpose of identifying settlements with greater potential for loss, where more urgent mitigation strategies and interventions to improve population safety are needed.

The civil parish of Alvares is located in a central-inner region of the Portuguese mainland, Pinhal Interior, in the southern part of Góis municipality (Fig. 1). It has an area of ca. $100 \mathrm{~km} 2$, of which forested areas occupy over $90 \%$. 


\section{Materials and Methods}

\section{Study area}

According to the last population Census survey (INE, 2012), the civil parish has 812 inhabitants, spread over nearly 40 small settlements. The three largest villages are located in the south and east, whereas the northwest corner of the civil parish is mainly occupied by a natural protected area. Almost half of the population is above 65 years old (47\%), $17 \%$ are illiterate and only $28 \%$ of residents are economically active.

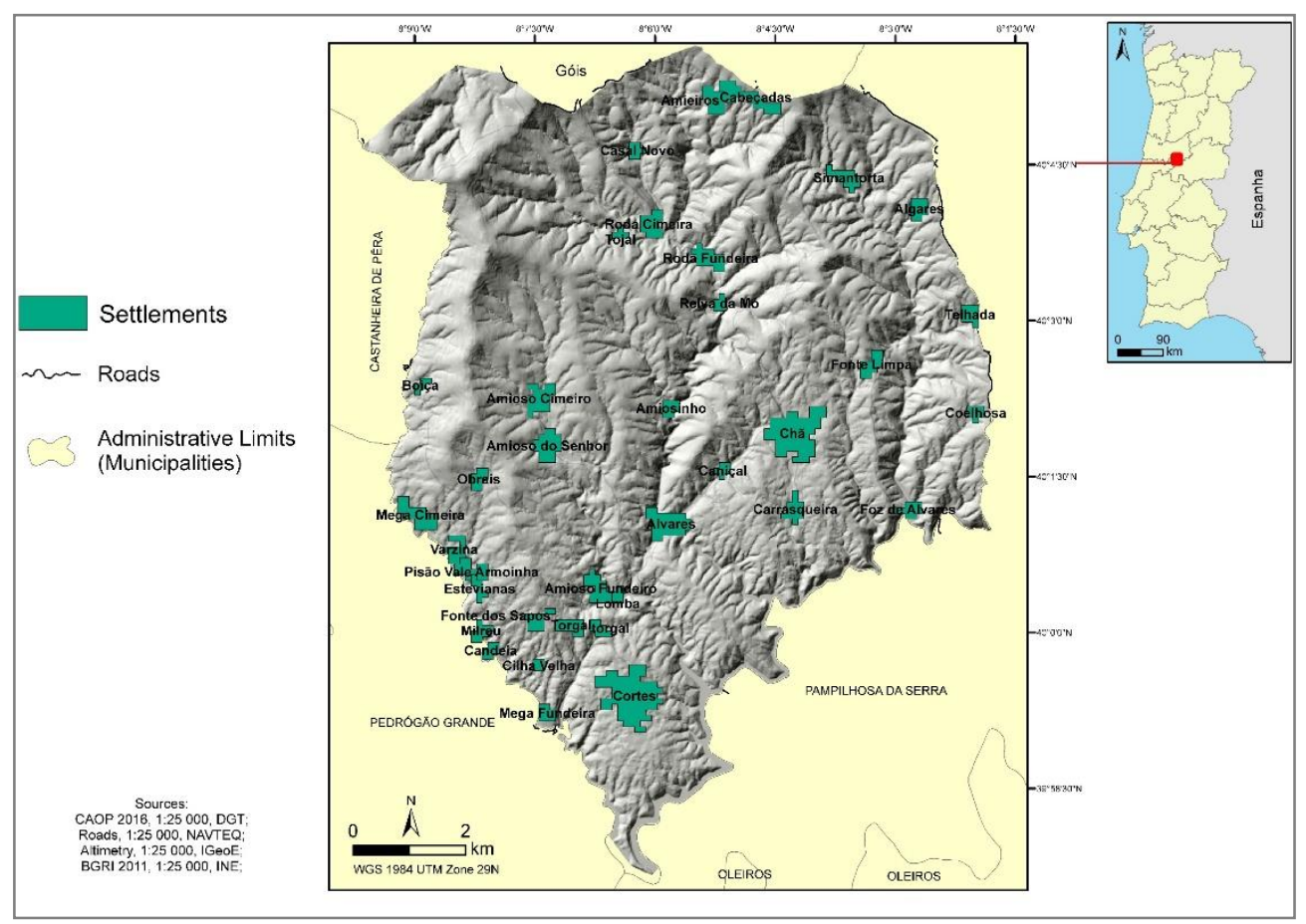

Figure 1 - Location of the human settlements in the civil parish of Alvares, Góis

\section{Exposure assessment}

Wildfire exposure was assessed at settlements scale within the civil parish. It generally represents the probability of wildfires causing damages to the population and existing assets within the settlements. The perimeters of the settlements were obtained from cartographic data available from local sources, specifically municipal institutions. To harmonize with the scale used in fire hazard modelling ( $1 \mathrm{ha}$ ), these perimeters were adjusted to include all the 1 ha pixels where human structures belonging to that settlement exist. We have then identified the exposed tangible assets located within the perimeter of each settlement, namely people, buildings and roads, retrieved from the most recent statistical and cartographic sources and at the smallest unit area possible (i.e. sub-section within the civil parish; INE 2012). Subsequently, their density was computed for the total area of the settlements and a combined index was obtained by summing the values for all the three parameters, weighted according to the municipal plans for protection against wildfires (AFN, 2012): population with higher weighting (1), followed by buildings $(0.75)$ and roads $(0.25)$. This index was then normalized into a common scale (0-100) to allow comparisons.

Afterwards, the index representing the elements exposed was combined with a burn probability measure for each unit area, applying three different approaches: i) static; ii) structural; and iii) dynamic. Static exposure considers a constant value of burn probability for the entire study area, therefore focusing on the existing assets. The structural exposure integrates historical burned area data to evaluate the number of times each settlement was affected by a fire between 1980 and 2017. The 
dynamic exposure was analyzed using burn probability simulations obtained with the FARSITE model (Finney, 1998), assuming different scenarios of land cover, extreme weather conditions and forest management options.

\section{Vulnerability assessment}

Vulnerability represents the degree of loss that can result from a wildfire, depending on the characteristics of the population and exposed assets (Aubrecht, Özceylan, Steinnocher, \& Freire, 2013; Gallina et al., 2016; UNISDR, 2009). Data on demographic and socioeconomic conditions were obtained from the 2011 Census survey (INE, 2012). Age groups, education levels, activity, building age and number of vacant houses, among other parameters, were retrieved and analyzed for each settlement.

\section{Results}

First results show that $33 \%$ of the settlements have high and very high structural exposure, corresponding generally to those settlements that were burned within their perimeter more than twice since 1980 (Fig. 2). When integrating the burn probability, considering land cover and weather conditions similar to those verified in 2017, the proportion of settlements in the higher exposure classes increased to $42 \%$.

Regarding vulnerability, about half of the settlements have more than $50 \%$ of elderly residents. Education levels are generally low, with $22 \%$ of settlements presenting more than $50 \%$ of people with only elementary education and $14 \%$ have more than $40 \%$ of illiterate people. The proportion of vacant housing is above $10 \%$ in $56 \%$ of the settlements (Fig. 3). In the settlements with high and very high structural exposure, the mean proportion of elderly people is $51 \%$ and the mean proportion of people with only elementary school level is $42 \%$.

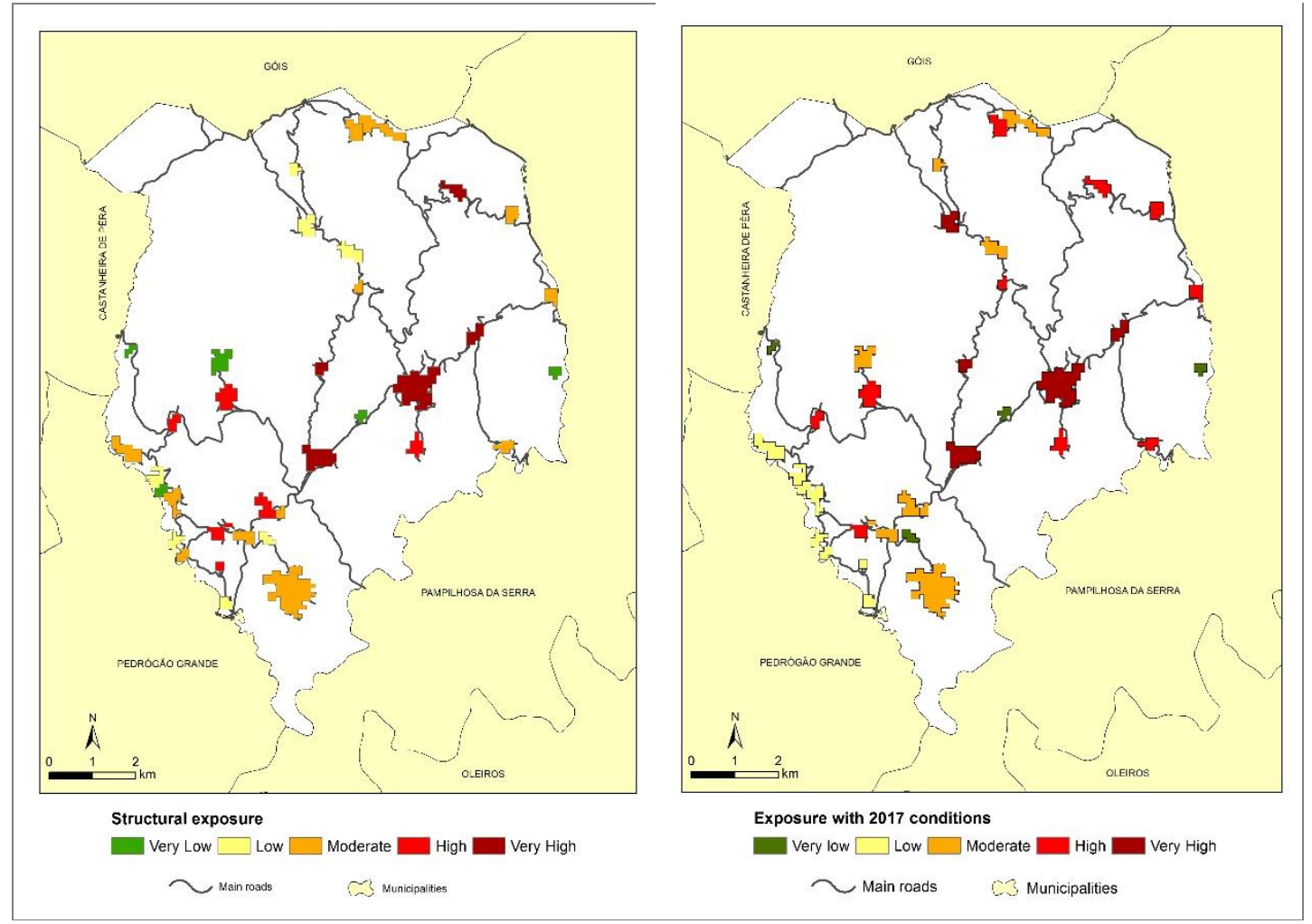

Figure 2 - Structural exposure (left) and exposure with 2017 conditions (right) for the human settlements in the civil parish of Alvares 
These conditions represent the overall social context of the local communities, which influence the coping capacity of the population and the type of protection and mitigation operational measures that could be efficiently implemented to reduce the levels of exposure and vulnerability to wildfires (Oliveira et al., 2017; Paveglio, Abrams, \& Ellison, 2016).
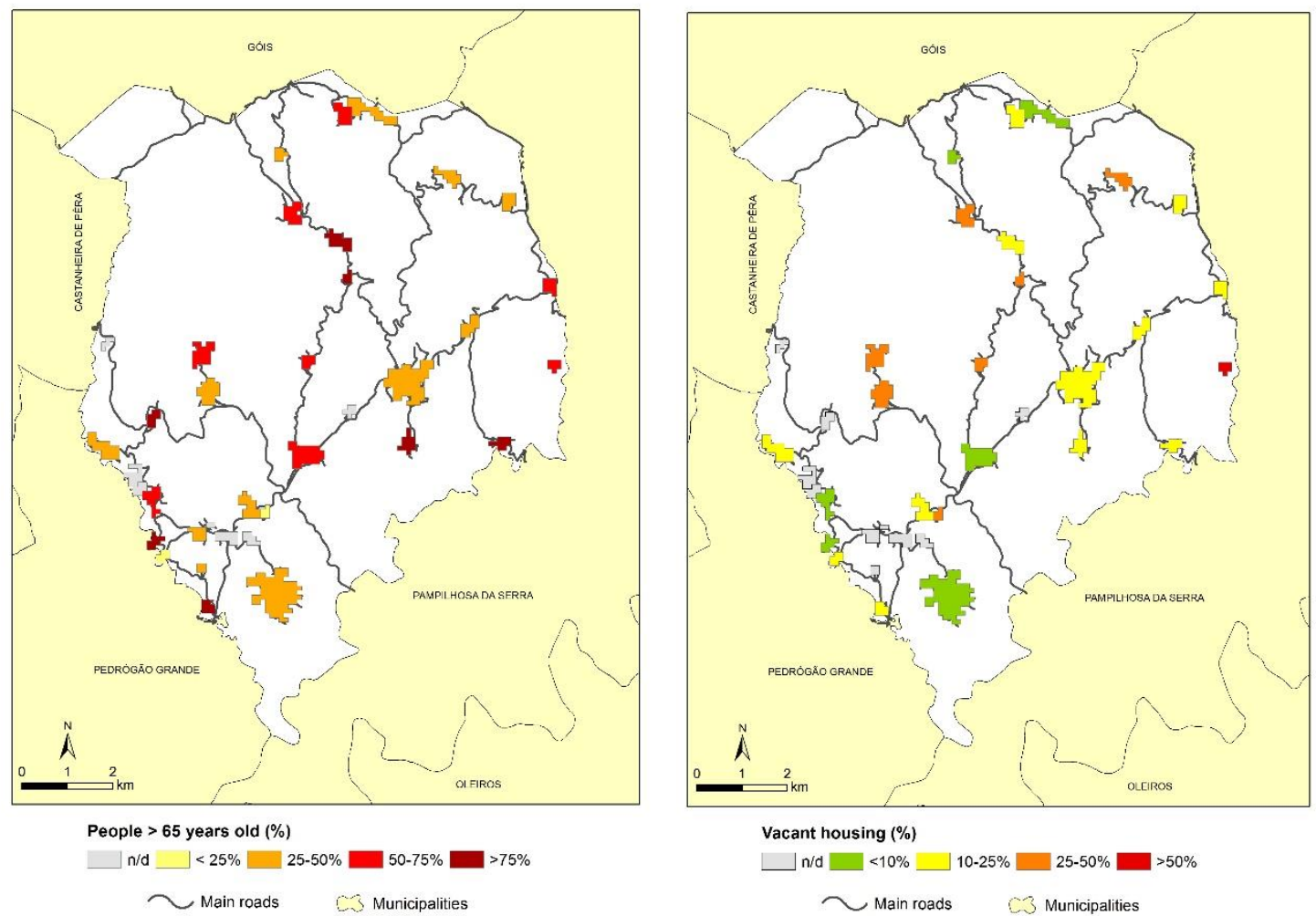

Figure 3 - Some of the vulnerability factors analyzed at settlement level: proportion of elderly people (left) and proportion of vacant housing (right)

\section{Further work}

The next step of this research will analyze the dynamic exposure, by evaluating potential changes in the exposure levels of settlements by integrating the effects of different weather and land cover conditions on burn probability simulations. Assessing these potential exposure variations will provide valuable indications regarding potential adjustments of mitigation measures to the characteristics and needs of the population, according to dynamic factors that influence wildfire exposure.

\section{References}

AFN, Autoridade Florestal Nacional (2012). Plano municipal de defesa da floresta contra incêndios (PMDFCI) - Guia técnico. Direção de Unidade de Defesa da Floresta.

Alcasena, F. J., Salis, M., Ager, A. A., Arca, B., Molina, D., \& Spano, D. (2015). Assessing Landscape Scale Wildfire Exposure for Highly Valued Resources in a Mediterranean Area. Environmental Management, 55(5), 1200-1216. http://doi.org/10.1007/s00267-015-0448-6

Aubrecht, C., Özceylan, D., Steinnocher, K., \& Freire, S. (2013). Multi-level geospatial modeling of human exposure patterns and vulnerability indicators. Natural Hazards, 68(1), 147-163. http://doi.org/10.1007/s11069-012-0389-9 
Carroll, M. S., \& Paveglio, T. B. (2016). Using community archetypes to better understand differential community adaptation to wildfire risk. Philosophical Transactions of the Royal Society of London B: Biological Sciences, 371(1696). http://doi.org/10.1098/rstb.2015.0344

Gallina, V., Torresan, S., Critto, A., Sperotto, A., Glade, T., \& Marcomini, A. (2016). A review of multi-risk methodologies for natural hazards: Consequences and challenges for a climate change impact assessment. Journal of Environmental Management, 168, 123-132. http://doi.org/10.1016/j.jenvman.2015.11.011

Moreira, F., Viedma, O., Arianoutsou, M., Curt, T., Koutsias, N., Rigolot, E., ... Bilgili, E. (2011). Landscape-wildfire interactions in southern Europe: Implications for landscape management. Journal of Environmental Management, 92(10), 2389-2402. http://doi.org/10.1016/j.jenvman.2011.06.028

Oliveira, S., Zêzere, J. L., Queirós, M., \& Pereira, J. M. (2017). Assessing the social context of wildfire-affected areas. The case of mainland Portugal. Applied Geography, 88, 104-117. http://doi.org/10.1016/j.apgeog.2017.09.004

Paveglio, T. B., Abrams, J., \& Ellison, A. (2016). Developing Fire Adapted Communities: The importance of Interactions Among Elements of Local Context. Society \& Natural Resources, 29(10), 1-16. http://doi.org/10.1080/08941920.2015.1132351

Paveglio, T. B., Prato, T., Edgeley, C., \& Nalle, D. (2016). Evaluating the Characteristics of Social Vulnerability to Wildfire: Demographics, Perceptions, and Parcel Characteristics. Environmental Management, 58(3), 534-548. http://doi.org/10.1007/s00267-016-0719-x

UNISDR. (2009). Terminology on Disaster Risk Reduction. United Nations International Strategy for Disaster Reduction (UNISDR). 